\title{
Marburg workers battle to win trust of locals
}

Emma Marris

An outbreak of Marburg disease in Angola's Uíge province is spreading, despite the best efforts of several relief organizations. Western aid workers have been unable to win the trust or understanding of locals, and have even come under attack.

Marburg is a rare virus from the same family as Ebola. Few people survive the haemorrhagic fever it causes, but in general the virus is contracted only from people who are visibly sick or dead. In theory, it should be simple to contain an outbreak by keeping such people in isolation.

"There is no vaccine, there is no cure. We have to break the transmission cycle by letting people know not to have contact with the dead," says Dave Daigle, a spokesman in Uíge for the World Health Organization. However, this causes conflict with families, who want to nurse their sick relatives and prepare bodies for burial.

IMAGE

UNAVAILABLE FOR COPYRIGHT REASONS

Workers are trying to quarantine patients, and are sprinkling bleach on body bags in an effort to replace the strong local custom of washing dead bodies. But the paper-suited, respirator-wearing strangers who arrive at the homes of suspected cases by truck or helicopter and attempt to remove the ill or dead from their families have been met by resentment and, on several occasions, rocks.

Relief organizations are scrambling for ways to break this cultural impasse. Aid workers are now accompanied by anthropologists and health educators to help mollify families and convince them to part with their relatives. Religious leaders, including the local Catholic bishop, are being drafted to disseminate news about steering clear of the infected, and the Angolan Red Cross is going door to door.

The remaining members of a traditional band that lost its lead singer to the virus have even put out a song with lyrics about defeating the disease and cooperating with health workers. Called Marburg, it is being played on the radio and from the loudspeakers of roving trucks.

The World Health Organization and other aid agencies are working to contain the disease, but the death toll, now at more than 200 , continues to rise. "I'd like to tell you that the numbers are contained, but they are not," says Daigle.

\section{Computer conference welcomes gobbledegook paper}

\section{Philip Ball}

Most graduate students would be delighted to have a paper accepted for presentation at an international scientific conference. But Jeremy Stribling, a computer-science graduate at the Massachusetts Institute of Technology (MIT) in Cambridge, wasn't sure whether to be amused or alarmed.

His paper, "Rooter: a methodology for the typical unification of access points and redundancy", co-authored with Daniel Aguayo and Maxwell Krohn, was accepted for the 9th World Multi-Conference on Systemics, Cybernetics and Informatics (WMSCI), to be held in Florida, in July. But Stribling didn't write it; he let a computer do it.

Stribling and his colleagues have developed an 'automatic computer-science paper generator' that cobbles together articles adorned with randomly generated graphs. The 'results' are totally spurious.

The MIT researchers say they hoped to cause "maximum amusement" by aping the jargon of the less illustrious papers in computer science. But they also had a more serious goal: to test whether such meaningless manuscripts could pass the screening procedure for conferences that, they feel, exist simply to make money.

'Rooter' passed the test: the WMSCI accepted it, albeit without peer review. The paper claims, among other things, that "the famous ubiquitous algorithm for the exploration of robots by Sato et al. runs in $\Omega((n+\log n))$ time".

It's not the first example of a hoax paper aimed at exposing poor reviewing and meaningless jargon. In 1996, US physicist Alan Sokal published a paper on the "hermeneutics of quantum gravity" in the journal Social Text. Sokal's paper parodied the post-modernist language of some contributions to that publication and prompted a vigorous debate about the intellectual respectability of 'cultural studies'.

The WMSCI conferences have been running for ten years, and last year's meeting attracted nearly 3,000 papers. WMSCI 2005 advertises itself as "trying to bridge analytically with synthetically oriented efforts, convergent with divergent thinkers".

The MIT team regards it as one of many conferences that have no scientific function and sell themselves through indiscriminate e-mails. "You see lists of speakers, and there's no one you've ever heard of," says Stribling. "They spam us."

Such conferences have sparked anger in the field, as demonstrated by a WMSCI submission from David Mazières of New York University and Eddie Kohler of the University of California, Los Angeles. The title, text and figures of their ten-page paper consist entirely of the phrase "Get me off your fucking mailing list".

"I don't know why these conferences exist," adds Frans Kaashoek, a member of the MIT computer-science group to which Stribling and his colleagues belong.

But the WMSCI's general chairman, Nagib Callaos, who is based in Venezuela and has no listed academic affiliation, has defended the conference's decision. "We did not receive reviews for some papers," Callaos says. "Since we thought that it was not fair to reject those, we accepted them as non-reviewed ones." The MIT paper has now been pulled. 